\title{
Comparative effects of kaolin and calcium carbonate on apple fruit surface temperature and leaf net $\mathrm{CO}_{2}$ assimilation
}

\author{
H.L. Alvarez ${ }^{a *}$, C.M. Di Bellab ${ }^{b}$ G.M. Colavitaa ${ }^{a}$ P. Oricchio ${ }^{b}$ and J. Strachnoyb \\ ${ }^{a}$ Facultad de Ciencias Agrarias, National University of Comahue, Ruta 151 km 12, 8303 Cinco Saltos R.N., Argentina \\ ${ }^{b}$ Instituto de Clima y Agua - INTA - Los Reseros y Las Cabañas S/N (B1712WAA), Castelar, Buenos Aires, Argentina. \\ *E-mail: hugo.alvarez@faca.uncoma.edu.ar
}

\begin{abstract}
The use of reflective particles on apple fruits has been suggested as a tool to diminish its thermal charge and thus mitigate stress effects caused by high temperature. The products effectiveness is often expressed in terms of damaged fruit, however it is influenced by the sensitivity of the variety, growing conditions and application method. Therefore, it is necessary to quantify the temperature of the fruits surface (FST) achieved according to the residue deposited to determine the degree of thermal protection for each product. Moreover, the residue deposited in the canopy enhances the albedo on the leaves reduces the availability of incidental light. The goal of this work was to evaluate the efficiency of reflective particles in the reduction of superficial temperature of the fruits and its effect on net $\mathrm{CO}_{2}$ assimilation rate $\left(A_{C O}\right)$ in apple trees (Malus domestica, Borkh). The fruits were treated with: one, two and four (1X; $2 \mathrm{X}$ and $4 \mathrm{X}$ ) applications of kaolin (treatment $\mathrm{K}$ ) or calcium carbonate (treatment $\mathrm{C}$ ) at $2.5 \% \mathrm{P} / \mathrm{V}$ and untreated fruit as control. The residue effect on $A_{\mathrm{CO}_{2}}$ was evaluated in individual leaves at $2 \mathrm{X}$ concentration. Both products showed a thermic protective effect as compared with control. The protection degree depended upon the concentration. The highest temperature of the control was $49.8^{\circ} \mathrm{C}$ and in these conditions kaolin was significantly more effective than carbonate, the thermic reduction was $1.9^{\circ} \mathrm{C}$ vs. $1.3{ }^{\circ} \mathrm{C}$ at $2 \mathrm{X}$ and $2.5^{\circ} \mathrm{C}$ vs $2.1{ }^{\circ} \mathrm{C}$ at $4 \mathrm{X}$ for kaolin and carbonate, respectively. At $1 \mathrm{X}$ there were no statistical differences between products. In turn $A_{\mathrm{CO} 2}$ is only negatively affected under low intensities of light $\left(<700 \mu\right.$ moles $\mathrm{m}^{2} \mathrm{~s}^{-1}$ of PAR). Higher radiation levels compensate the shading effect over leaves and also the maximun $A_{\mathrm{CO}_{2}}\left(A_{\max }\right)$ was not affected.
\end{abstract}

Key words: Heat stress, infrared thermography, leaf photosynthesis, Malus domestica, particle film, sunburn protection

\section{Introduction}

Stress caused by high temperatures, together with direct solar radiation in apple [Malus sylvestris (L.) Mill var. domestica (Borkh.) Mansf.] orchards develop a physiopathy called sunburn which significantly affects the quality of the fruits (Schrader et al., 2001; Racskó et al., 2005). Shrader et al. (2001) stated two types of sunburn according to fruit surface temperature: "sunburn necrosis" caused by necrosis in superficial tissues when temperature of the fruits surface (FST) reaches $51-52^{\circ} \mathrm{C}$ and "sunburn browning", which is a yellow or bronze stain on the fruit skin caused by lower temperatures $\left(46-49^{\circ} \mathrm{C}\right)$ and the presence of ultraviolet radiation (UV). The damage severity depends mainly of the temperature reached by the fruit surface and also it is influenced by own sensitivity of cultivar, the weather conditions and handling practices (Parchomchuk et al., 1996; Schrader et al., 2003).

The use of reflective particles on fruits has been suggested as a tool to diminish its thermic charge because it reduces the incident radiation that can be absorbed by the fruits (Glenn et al., 2002; 2003, 2009; Wuncshe et al., 2004) and thus reduce the incidence of sunburn (Glenn et al., 2002; Gindaba et al., 2005; Wand et al., 2006; Colavita, 2011). The nature of particles generally comprises minerals of high reflectivity, among them kaolin and calcium carbonate are alternatives of relative low cost, safe use, low erosion, reduced particle size and water diffusion ability (Glenn et al., 2003). When the effectiveness of the products is expressed in terms of damaged fruit, it is influenced by the sensitivity of the variety, growing conditions and application method (Glenn et al., 2002; Erez et al., 2004). Therefore, to determine the degree of thermal protection for each product it is necessary to quantify the FST achieved according to the residue deposited on the fruit surface. Moreover, the residue of the products over the leaf enhances its albedo and reduces the absorption of photosynthetically active radiation. There exists discrepancy over the effect of the use of reflective particles in relation to the rate of net assimilation of $\mathrm{CO}_{2}$. Some authors have reported positive effects under saturated light conditions on apple trees leaves (Glenn et al., 2001) and pomegranate (Punica granatum L.) (Melgarejo et al., 2004). However, Gindaba et al. (2007) in apple trees and Rosati et al. (2007) in walnuts (Junglans regia L.) and almond trees [Prunus dulcis (Mill.) DA Webb] did not find a significant effect on the net $\mathrm{CO}_{2}$ assimilation rate when applying kaolin even under satured conditions. Contrarily, Schupp et al. (2002) reported in Fuji apple trees - treated with three kaolin applications at $3 \%(\mathrm{~m} / \mathrm{V})$ - a smaller productivity and size of fruits, they attributed this to a lesser light availability to develop photosynthesis. In the same line of thought, Wunsche et al. (2004b) and Le Grange et al. (2004) observed a decreased rate of net $\mathrm{CO}_{2}$ assimilation in apple trees treated with reflective particles and they associated it with the effect of a lower light incidence.

The aim of the present work was to measure the efficiency of each reflective particle films of kaolin and carbonate calcium in 
the reduction of superficial temperature of the fruits and its effect on the net $\mathrm{CO}_{2}$ assimilation rate in apple trees.

\section{Materials and methods}

Degree of thermic protection: The grade of thermic protection was evaluated according to the quantity of residue settled on the surface and to the nature of the protecting product at the moment of highest warming. Two commercial products were used for the development of reflective particle films: one based on kaolin processed up to a diameter lower than $2 \mu \mathrm{m}(\mathrm{K})$ and another one based on calcium carbonate $(97 \%)$ and zinc oxide $(3 \%)$ (C). At harvest time, 70 fruits of similar size were picked from an apple orchard $c v$. Granny Smith, trained as palmette leader in the experimental farm of National University of Comahue (38 50 '44"S, 68 $04^{\circ}$ '11'W). They were divided in seven groups each with ten repetitions following a completely random design and then were applied the following treatments: one (1X), two (2X) and and four (4X) applications of kaolin or carbonate at $2.5 \%$ $m / V$ (treatment $\mathrm{K}$ or treatment $\mathrm{C}: 1 \mathrm{X} ; 2 \mathrm{X}$ and $4 \mathrm{X}$, respectively) and other fruits with no treatment as (control). The applications were carried out with a hand atomizer and an intermediate drying time was allowed between each one. To allow more homogeneous conditions, all fruits were exposed to the sun simultaneously, in a broad area, far away from the influence of vegetation and the increase of surface temperature was measured through the record of six thermic images from 11:15 h untill 15:30 h, moment in which the temperature over them begun to decline. The thermic images were taken using an infrared camera, Handy Thermo TVS-200 Inframetrics thermal IR video imagery system (Nippon Avionics co. LTD, Tokyo, Japan). The focal distance used was $1.0 \mathrm{~m}$, and spatial resolution was $1.68 \mathrm{~mm}$. The emissivity value was adjusted in 0.95 (Hellebrand et al., 2001). In each fruit a circular area of 111 pixels was selected (approximate radius $=1$ $\mathrm{cm}$ ), centered on that pixel of highest temperature identified in the fruit. The average temperature of each area identified (FST) was considered as the highest thermic increase reached by the fruit at the moment of taking measurements. A second grade function, FST vs. time ( $\mathrm{t}$ ) was adjusted, and the maximum temperature reached for each treatment $\left(\mathrm{FST}_{\max }\right.$ ) was determined from the derivative of the function corresponding.

During the test, the air temperature ranged between 21.5 and $29.0{ }^{\circ} \mathrm{C}$, the relative humidity fell from 40 to $25 \%$ and the wind did not exceed $0-2 \mathrm{~m} / \mathrm{s}$. The highest hourly average radiation was of 624.8 watts $\mathrm{m}^{-2}$ and was registered at 13:00 PM. For each fruit the residue deposited on the surface (SR) was removed and quantified as $\mu \mathrm{g} / \mathrm{cm}^{2}$.

The means differences between treatments were assessed by the least significant difference (LSD) or Fisher test.

Light response: The work was carried on apple trees cv Royal Gala of about 9 years old, homogeneous in height and strength trained as palmette leader, with a plantation frame of $4.0 \times 1.5$ $\mathrm{m}$, and mechanical irrigation. Five weeks after comercial harvest seven exposed shoots of similar size, strength and orientation distributed in adjacent trees were selected. In middle zone of each bud, three completely expanded adjacent leaves, were randomly treated with: kaolin $5.0 \%(\mathrm{~m} / \mathrm{V})$ (treatment $\mathrm{K})$; carbonate $5.0 \%$ $(\mathrm{m} / \mathrm{V})$ (treatment $\mathrm{C})$; and no treatment as control (Control). In order to avoid accidental contamination during the applications, those marked leaves were protected with aluminum foil. The applications were performed 7 days before taking measurements. The measurement of gas interchange was taken in each leaf, between 09:30 AM (1 h 56 min after sunrise) and 13:30 PM (midday sun), using CIRAS-1 Analyzer; PP System, (Haverhill, MA, USA). The camera settings were programmed with $350 \mathrm{ppm}$ $\mathrm{CO}_{2} ; 25^{\circ} \mathrm{C}$ and 7 levels of photosynthetically active radiation (PAR): $0 ; 100 ; 200 ; 400 ; 600 ; 800$ and $1000 \mu$ moles $\mathrm{m}^{-2} \mathrm{~s}^{-1}$, respectively. The net $\mathrm{CO}_{2}$ assimilation $\left(A_{\mathrm{CO}_{2}}\right)$ was registered in $\mu$ moles $\mathrm{m}^{-2} \mathrm{~s}^{-1}$. Recorded data were fitted to non rectangular hyperbola (Lambers et al., 1998), using a no linear adjustment procedure (Statistica, StatSoft, Inc Tulsa, USA); (Equation 1),

$A_{\mathrm{CO}_{2}}=\left\{\Phi x P A R+A_{\max }-\left[(\Phi x P A R)^{2}-4 \Phi x P A R x \Theta x A_{\max }\right]^{1 / 2}\right\} /\left(2 \Theta-R_{o}\right)$ Ec. 1

where, $A_{\mathrm{CO}_{2}}$ is the rate of net $\mathrm{CO}_{2}$ assimilation ( $\mu$ moles $\mathrm{m}^{-2} \mathrm{~s}^{-1}$ ); Phi $(\Phi)$, is the apparent quantum efficiency and relates $\mathrm{CO}_{2}$ mass fixed by mole of incidental photon, which graphically is associated to initial slope of the curve; PAR, photosynthetically active incidental radiation ( $\mu$ moles $\left.\mathrm{m}^{-2} \mathrm{~s}^{-1}\right) ; \mathrm{A}_{\max }$, theoretical rate of net $\mathrm{CO}_{2}$ assimilation in saturated conditions of PAR; Tita $(\Theta)$, is the curvature factor, which varies between 0 and 1 . When $\Theta$ has values near to 1 , the curve changes directly from its initial gradient determined by $\Phi$ to a plateau (Blackman curve) determined by $\mathrm{A}_{\max }$ and dark respiration (Ogren, 2003). For those values smaller to 1 , the curve becomes a hyperbola. $\mathrm{R}_{0}$ represents the dark respiration of the leaf under $\mathrm{PAR}=0$ conditions. PAR in $A_{\mathrm{CO}_{2}}=0$ value is the point of light compensation $\left(\mathrm{CP}_{\mathrm{L}}\right)$ for this level of $\mathrm{CO}_{2}$.

After gas interchange measurements, leaves were cut and SR was assessed. The leaf area determined with the leaf area meter Li-Cor 3100 (Li-Cor Inc., Lincoln, NE, USA).

Products reflectance: Spectral reflectance of products was assessed in the range of photosynthetically active radiation (PAR) (400-700 nm) over a flat, homogeneous surface of $1.0 \mathrm{~cm}$ thickness, using a spectral radiometer FieldSpec ${ }^{\mathrm{TM}}$ Analytical Spectral Devices, Inc. (ASD) 5335 Sterling Drive; Suite A Boulder; CO 80301 USA. As a reference, we used the polytetrafluoroethylene standard (PTFE), Spectralon ${ }^{\mathrm{TM}}$, with a 99\% of reflectance (Weidner et al., 1981). All measurements were taken under conditions of natural midday light, over three different surface points, using an average of 5 marks in each point.

\section{Results and discussion}

Thermic protection degree: The surface temperature of treated fruit during the warming period was lowered as compared to control for all used concentrations (Table 1). Untreated fruits, exposed to sun and without protective effect of vegetation reached a FST of $49.8^{\circ} \mathrm{C}$, a value of about $20^{\circ} \mathrm{C}$ higher than the surrounding air. Measurements of the temperature on exposed fruits surface in each tree have established differences from 10 to $15^{\circ} \mathrm{C}$ higher to the air temperature (Thorpe, 1974; Shrader et al., 2003), this issue highlights the importance of thermic influence of the canopy over the fruits surface temperature. Furthermore the thermal distribution in the canopy is not uniform. Stajnko et al. (2003) reported FST variations inside the canopy from 24 to $40{ }^{\circ} \mathrm{C}$ in Gala apple trees. However, even in fruits isolated 
Table 1. Maximum temperature estimated during test $\left(\mathrm{FST}_{\max }\right)$ at the moment of further warming; temperature decrease (TD) of treatments $\mathrm{C}$ (calcium carbonate) and $\mathrm{K}$ (kaolin) as compared to Control. Amount of residue recovered of fruit surface (SR). Air temperature: $28.9^{\circ} \mathrm{C}$

\begin{tabular}{lccccccc}
\hline Patameters & \multicolumn{5}{c}{ Treatment } \\
\cline { 2 - 7 } & Control & \multicolumn{5}{c}{$\mathrm{C}$} & \multicolumn{3}{c}{$\mathrm{K}$} \\
\hline $\mathrm{TSF}_{\text {max }}{ }^{2}\left({ }^{\circ} \mathrm{C}\right)$ & $49.8 \mathrm{a}$ & $48.7 \mathrm{~b}$ & $48.5 \mathrm{c}$ & $47.7 \mathrm{~d}$ & $48.7 \mathrm{bc}$ & $47.8 \mathrm{~d}$ & $47.1 \mathrm{e}$ \\
$\mathrm{TD}\left({ }^{\circ} \mathrm{C}\right)$ & 0 & -1.1 & -1.3 & -2.1 & -1.0 & -1.9 & -2.5 \\
$\mathrm{SR}^{\mathrm{y}}\left(\mathrm{mg} / \mathrm{cm}^{2}\right)$ & 0 & $250.9 \mathrm{a}$ & $385.6 \mathrm{~b}$ & $526.2 \mathrm{c}$ & $204.7 \mathrm{a}$ & $349.9 \mathrm{~b}$ & $554.3 \mathrm{c}$
\end{tabular}

${ }^{2}$ TSFmax is maximun of funtion TSF $=a \cdot t^{2}+b \cdot t+c$ which represents observed values in each treatment.

${ }^{y}$ Different letters in row indicate significant differences by LSD Fisher test $(P<0.05)$.

from the canopy influence, our results indicate a protective effect achieved by the application of reflective particles. At the moment of highest warming, treatment $\mathrm{C}$ significantly lowered surface temperature in relation to control by $1.1 ; 1.3$ and $2.1^{\circ} \mathrm{C}$ for $1 \mathrm{X}, 2 \mathrm{X}$ and $4 \mathrm{X}$ concentrations, respectively; treatment $\mathrm{K}: 1.1$; 2.1 and $2.5{ }^{\circ} \mathrm{C}$ for $1 \mathrm{X}, 2 \mathrm{X}$ and $4 \mathrm{X}$ concentrations, respectively (Table 1). Nevertheless, the scale of thermic decrease coincides only partially with the ones of other authors who have worked with the fruits in the plant. Glenn et al. (2002), observed a range of thermic decrease with kaolin of 1.4 to $3.4^{\circ} \mathrm{C}$ in "Fuji" apple trees and subsequently of 4.0 to $4.3{ }^{\circ} \mathrm{C}$ in "Scarlet Delicious" when the average surface residue in these fruits was of 548 and $508 \mu \mathrm{g} \mathrm{cm}^{-2}$, respectively. In our working conditions, using comparable amounts of kaolin $\left(554.3 \mu \mathrm{g} \mathrm{cm}^{-2}\right)$, we estimated a maximun decrease up to $2.5^{\circ} \mathrm{C}$ on treated fruits in relation to control (Table 1). Gindaba et al. (2005) reported temperature decreases of 1.5 to $6.4{ }^{\circ} \mathrm{C}$ in "Cripps Pink" and "Royal Gala" apples when two applications of kaolin $(6 \%$ and $3 \% \mathrm{~m} / \mathrm{V})$ were applied at interval of 5 weeks.

SR on the fruits was significatively different between treatments, however, it did not increase in linear proportion with the number of applications at $2.5 \% \mathrm{~m} / \mathrm{V}$ (Table 1). Application conditions can modify the quantity of settled residue. Glenn et al. (2002) also reported important differences in the fruits residue collected with the same number of kaolin applications. This suggests the need to index the effect of reflective particles to the amount of current residue by surface unit, at the moment of taking the measurements.

Light response: The observed values of $A_{\mathrm{CO}_{2}}$, corresponding to PAR are shown in Fig. 1. Data was represented through a non rectangular hyperbola (Lambers et al., 1998); with $\mathrm{R}^{2}$ : 0.93; 0.96 and 0.92 for $\mathrm{K}, \mathrm{C}$ and control, respectively. When the PAR level was lower than $700 \mu$ moles $\mathrm{m}^{-2} \mathrm{~s}^{-1}, A_{\mathrm{CO}_{2}}$ in Control was higher as compared to treatments. At PAR $=200 \mu$ moles $\mathrm{m}^{-2} \mathrm{~s}^{-1}$ the value of $A_{\mathrm{CO}_{2}}$ reached by the control (4.03 $\mu$ moles $\mathrm{CO}_{2} \mathrm{~m}^{-2}$ $\left.\mathrm{S}^{-1}\right)$ was significantly higher than the treatment $\mathrm{K}(2.79 \mu$ moles $\left.\mathrm{CO}_{2} \mathrm{~m}^{-2} \mathrm{~s}^{-1}\right)$, while treatment $\mathrm{C}$ showed intermediate values, but no significant differences $(P<0.01)$ (Table 2$)$. These results suggest a smaller availability of incident light on treated leaves, which shows itself with detriment to leaf $A_{\mathrm{CO}_{2}}$ to low radiation intensities. The differences between kaolin and carbonate are consistent with the greater reflectance of the first Reflenctancy data of products expressed as percentages of the reference pattern, showed a maximum reflectance of $85.5 \%$ for kaolin $v s .83 .4 \%$ for carabonate. The differences of reflectance between products in the PAR range fluctuated between 1.7 and $4.4 \%$ according to the wave length, being kaolin more reflective (Fig. 2). At PAR values higher to $700 \mu$ moles $\mathrm{m}^{-2} \mathrm{~s}^{-1}$ for treatment $\mathrm{C}$ and $900 \mu$ moles $\mathrm{m}^{-2}$ $\mathrm{s}^{-1}$ for treatment $\mathrm{K}$, the shading effect seems to be compensated. $A_{\mathrm{CO}_{2}}$ values on leaves treated with reflective particles film were increased at high levels PAR, though not showing significant statistical differences. This is consistent with non differences observed $(P<0.05)$ in the analysis of parameter $A_{\max }$ of equation 1 , which represents the maximum assimilation of $\mathrm{CO}_{2}$ when light is not limiting (Table 2). These results differ with Wunsche et al. (2004a), who reported a decrease of $20 \%$ of PAR absorption in apple leaves treated with kaolin, with negative effects on net $\mathrm{CO}_{2}$ assimilation rate. Gindaba et al. (2007) reported a negative effect on net $\mathrm{CO}_{2}$ assimilation rate in apple leaves treated with kaolin at the end of the growing stage. In almond trees, $2000 \mu$ moles $\mathrm{m}^{-2}$ $\mathrm{s}^{-1}$ of PAR were not sufficient to reach saturation on kaolin treated leaves at $6 \%$. $(\mathrm{m} / \mathrm{V})$, suggesting a strong shading effect on these reflective particles (Rosati et al., 2006). Quantum efficiency, $\Phi$, is related to the ability of electronic transport in the leaf (Iacono et al., 2004). In this work, $\Phi$ in control (0.030) was significatively higher as compared to treatments $\mathrm{C}(0.023)$ and $\mathrm{K}(0.020)$ whereas differences between $\mathrm{C}$ and $\mathrm{K}$ were not statistically significant $(P<0.05)$ (Table 2). These values reinforce the idea that the reflection of one part of incident radiation negatively affects the photosynthetic rate in individual leaves at low PAR intensities. Similar results in apples were reported by Le Grange et al. (2004). The parameter $\Theta$ represents the photosynthetic efficiency above the linear sector determined by $\Phi($ Ogren, 1993) and there exists evidences that $\Theta$ decreases with the increase of caraboxilative ability of Rubisco (Ogren and Evans, 1993). In our working conditions no significant differences were observed in relation

Table 2. Light response of apple leaves cv. Royal Gala, treated with kaolin $(\mathrm{K})$ and calcium carbonate $(\mathrm{C})$, at $5.0 \%(\mathrm{~m} / \mathrm{V})$, on apparent quantum efficiency $(\Phi)$, theoretical rate of net $\mathrm{CO}_{2}$ assimilation in saturated conditions of PAR $\left(\mathrm{A}_{\mathrm{max}}\right)$, the curvature factor $(\Theta)$; dark respiration $\left(\mathrm{R}_{\mathrm{o}}\right)$ and luminic compensation point $\left(\mathrm{CP}_{\mathrm{L}}\right)$

\begin{tabular}{|c|c|c|c|c|c|c|}
\hline \multirow[t]{2}{*}{ Treatment } & \multirow{2}{*}{$\begin{array}{l}\text { Residue } \\
\left(\mathrm{mg} \mathrm{cm}^{-2}\right)\end{array}$} & \multicolumn{5}{|c|}{ Parameter $^{z}$} \\
\hline & & $\Phi$ & $\begin{array}{c}\mathrm{A}_{\max } \\
(\mu \text { molesCO } \\
\left.2 \mathrm{~m}^{2} \mathrm{~s}^{-1}\right)\end{array}$ & $\Theta$ & $\begin{array}{c}\text { Ro } \\
\left(\mu \text { moles } \mathrm{CO}_{2} \mathrm{~m}^{2} \mathrm{~s}^{-1}\right)\end{array}$ & $\begin{array}{c}\mathrm{CP}_{\mathrm{y}}^{\mathrm{y}} \\
\left(\mu \text { moles RFA m}{ }^{2} \mathrm{~s}^{-1}\right)\end{array}$ \\
\hline K & $377.3 \mathrm{a}$ & $0.020 \mathrm{a}$ & $10.8 \mathrm{a}$ & $0.88 \mathrm{a}$ & $1.02 \mathrm{a}$ & $58.7 \mathrm{a}$ \\
\hline $\mathrm{C}$ & $396.4 \mathrm{a}$ & $0.023 \mathrm{a}$ & $10.5 \mathrm{a}$ & $0.83 \mathrm{a}$ & $1.24 \mathrm{a}$ & $54.7 \mathrm{a}$ \\
\hline Control & 0 & $0.030 \mathrm{~b}$ & $11.4 \mathrm{a}$ & $0.88 \mathrm{a}$ & $1.39 \mathrm{a}$ & $46.9 \mathrm{a}$ \\
\hline
\end{tabular}

${ }^{z}$ The parameters were calculated based on the average of the values generated for each sheet, based on the model:

$\mathrm{A}=\{\Phi \times \mathrm{xFA}+\mathrm{Amax}-[(\Phi \times \mathrm{RFA}) 2-4 \Phi \times \mathrm{RFAx} \Theta \mathrm{xAmax}] 1 / 2\} /(2 \Theta-\mathrm{Ro})$

${ }^{\mathrm{C}} \mathrm{P}_{\mathrm{L}}$ was calculated at $\mathrm{A}=0$.

Different letters in columns indicate significant differences by LSD Fisher test $(P<0.05)$. 


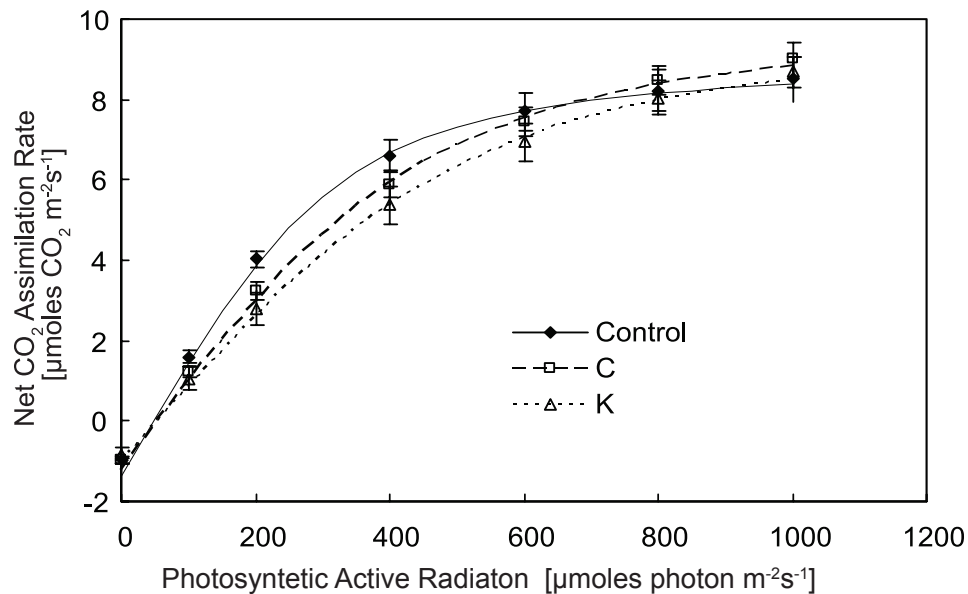

Fig. 1. Net $\mathrm{CO}_{2}$ assimilation $\left(A_{\mathrm{CO}}\right)$ in response to increasing of photosynthetically active radiation (PAR) in apple leaves cv. Royal Gala, treated with kaolin $5.0 \%$ $(\mathrm{m} / \mathrm{V})(\mathrm{K})$ and carbonate $5.0 \%(\mathrm{~m} / \mathrm{V})(\mathrm{C})$. The points in each treatment represent the mean \pm standard error.

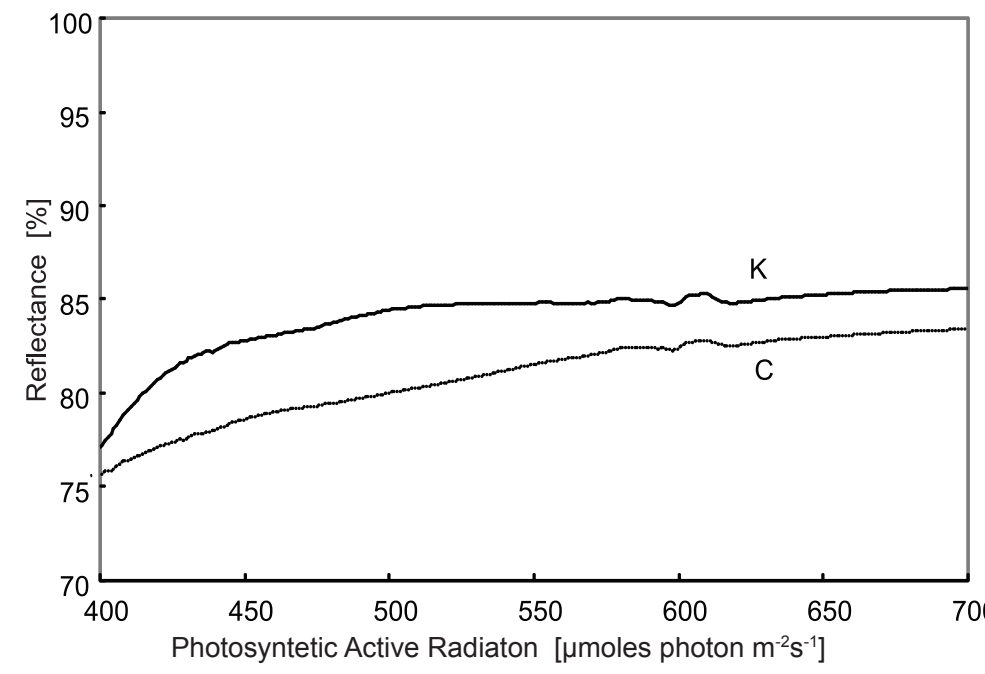

Fig. 2. Percent reflectance by wavelength, of a flat and uniform layer of $\mathrm{C}$ and $\mathrm{K}$, within the spectral range of the photosynthetically active radiation.

to this parameter between treatments (Table 2). Lambert et al. (1998) demonstrated that both dark respiration (Ro) and light compensation point $\left(\mathrm{CP}_{\mathrm{L}}\right)$ are higher in plants that are acclimatized to high light intensities compared to plants acclimatized to low light intensities. In this work, the effect of the low light availability caused by the treatments was not enough to establish significant differences over Ro and $\mathrm{CP}_{\mathrm{L}}$ during the experiment (Table 2).

Based on our results we can deduce that there exists a thermoprotector effect attributable to treatments. The degree of protection depends on the reflectance and the amount of residue settled on the surface. The amount of the residue settled on the fruit surface is affected by products and application conditions but not directly proportional to the number of applications of one determined concentration. The treatment difference was observed from one residue accumulation threshold. The degree of thermic protection reached in this test suggests the need of combining the use of reflective particle films together with other cultural practices that can contribute to decrease thermic charge on fruits, such as irrigation, training and prunning. In individual leaves $\mathrm{A}_{\mathrm{CO}_{2}}$ seems to affect negatively only to low light intensities (PAR $<700 \mu$ moles $\left.\mathrm{m}^{-2} \mathrm{~s}^{-1}\right)$, higher radiation levels compensate the effect of shadowing on the leaves even though not modifying the maximum ability of net $\mathrm{CO}_{2}$ assimilation.

\section{References}

Colavita, G.M., V. Blackhall and S. Valdez, 2011. Effect of kaolin particle films on the temperature and solar injury of pear fruits. Acta Hort., 909: 609-615.

Erez, A. and D.M. Glenn, 2004. The effect of particle film technology on yields and fruit quality. Acta Hort., 636: 505-507.

Gindaba, J. and S.J. Wand, 2005. Comparative effects of evaporative cooling, kaolin particle film, and shade net on sunburn and fruit quality in apples. HortScience, 40(3): 592-596.

Gindaba, J. and S.J.E. Wand, 2007. Climate-ameliorating measures influence photosynthetic gas exchange of apple leaves. Ann. Appl. Biol., 150: 75-80.

Glenn, D.M, G.J. Puterka, S.R. Drake, T.H. Unruh, A.L. Knight, P. Baherle, E. Prado and T. Baugher, 2001. Particle film application influences apple leaf physiology, fruit yield and fruit quality. $J$. Amer. Soc. Hort. Sci., 126(2): 175-181.

Glenn, D.M., E. Prado, A. Erez, J.R. McFerson and G.J. Puterka, 2002. A reflective processed kaolin particle film affects fruit temperature, radiation reflection and solar injury in apple. J. Amer. Soc. Hort. Sci., 127: 188-193.

Glenn, D.M., A. Erez, G.J. Puterka and P. Gundrum, 2003. Particle films affect carbon assimilation and yield in 'Empire' apple. $J$. Amer. Soc. Hort. Sci., 128: 356-362.

Glenn, D.M. 2009. Particle film mechanisms of action that reduce the effect on enviromental stress in 'Empire' apple. J. Amer. Soc. Hort. Sci., 134(3): 314-321.

Hellebrand, H.J., H. Beuche, M. Linke, B. Herold and M. Geyer, 2001. Chances and Shortcomings of Thermal Imaging in the Evaluation of Horticultural Products. International Conference "Physical Methods in Agriculture - Approach to Precision and Quality", Prague 27-30 August 2001, Proceedings, 112-117. (ISBN 80-213-0836-2).

Husen, J.I.A and L.I. Dequan, 2002. Relationship between photosystem 2 electron transport and photosynthetic $\mathrm{CO} 2$ assimilation responses to irradiance in young apple tree leaves. Photosynthetica, 40(1): 139-144.

Iacono, F., D. Porro and M. Stefanini, 2004. Radiación solar y fotosíntesis. - In: Formas de cultivo de la vid y modalidades de distribución de los productos. Balsari, P., Scienza, A. (ed.) Mundiprensa, Madrid - Barcelona - México. Pp. 85-101.

Lambers, H., F. Chapin and T. Pons, 1998. Photosynthesis, respiration and long-distance transport. In: Plant Physiological Ecology. Lambers, H.; Chapin F. and Pons, T (ed.): Springer-Verlag, New York. Pp. 10-125

Le Grange, M., S.J.E. Wand and K.I. Theron, 2004. Effect of kaolin applications on apple fruit quality and gas exchange of apple leaves. Acta Hort., 636: 545-550.

Melgarejo, P., J.J. Martinez, F. Hernandez, R. Martinez-Font, P. Barrows and A. Erez, 2004. Kaolin treatment to reduce pomegranate sunburn. Scientia Hort., 100: 349-353.

Ogren, E. 1993. Convexity of the photosynthetic light-response curve in relation to intensity and direction of light during growth. Plant Physiol., 101: 1013-1019.

Ogren, E. and J.R. Evans, 1993. Photosynthetic light response curves. I. The influence of $\mathrm{CO}_{2}$ partial pressure and leaf inversion. Planta, 189: 182-190.

Parchomchuk, P. and M. Meheriuk, 1996. Orchard cooling with pulsed over-tree irrigation to prevent sunburn and improve fruit quality of 'Jonagold' apples. HortScience, 31: 802-804.

Racskó, J., S.Thurzó, Z. Szabó and J. Nyéki, 2005. Effect of sunburn on Malus domestica (Borkh.) apples. Gesunde Pflanzen, 57(2-3): 47-52.

Rosati, A., S.G. Metcalf, R.P. Buchner, A.E. Fulton and B.D. Lampinen, 2006. Physiological effects of kaolin applications in well-irrigated and water-stressed walnut and almond trees. Ann. of Botany, 98: 267-275. 
Rosati, A., S.G. Metcalf, R.P. Buchner, A.E. Fulton and B.D. Lampinen, 2007. Effects of kaolin application on light absorption and distribution, radiation use efficiency and photosynthesis of almond and walnut canopies. Ann. of Bot., 99: 255-263.

Schrader, L.E., J. Zhang and W.K. Duplaga, 2001. Two types of sunburn in apple caused by high fruit surface (peel) temperature. Plant Health Progress. Online. doi:10.1094/PHP-2001-1004-01-RS.

Schrader, L., J. Zhang and J. Sun, 2003. Environmental stresses that cause sunburn of apple. Acta Hort., 618: 397-405.

Schupp, J., E. Fallahi and J. Chun, 2002. Effect of particle film on fruit sunburn maturity and quality of 'Fuji' and 'Honeycrisp' apple. Hort Technology, 12(1): 87-90.

Stajnko D., M. Lakota, M. Hocevar and Z. Cmelik, 2003. Application of termal Imaging for estimating current yield in the apple orchard. Die Bodenkultur, 54(3): 171-180.
Thorpe, M.R. 1974. Radiant heating of apples. Journal of Applied Ecology, 11(2): 755-760.

Wand, S.J.E., K.I. Theron, J. Ackerman and S.J.S. Marais, 2006. Harvest and post-harvest apple fruit quality following applications of kaolin particle film. South African orchards. Scientia Hort., 107: 271-276.

Weidner, V.R. and J.J. Hsia, 1981. Reflection properties of pressed polytetrafluoroethylene powder. J. Opt. Soc. Am., 71: 856-861.

Wünsche, J.N., L. Lombardini and D.H. Greer, 2004a. 'Surround' particle film applications-Effects on whole canopy physiology of apple. Acta Hort., 636: 565-571.

Wünsche, J.N., J. Bowen, I. Ferguson, A. Woolf and T. McGhie, 2004b. Sunburn On Apples - Causes and Control Mechanisms. Acta Hort., (ISHS) 636: 631-636.

Received: October, 2015; Revised: December, 2015; Accepted: December, 2015 